\title{
$\frac{26}{11 / 5 / 98} \mathrm{gs}$
}

\section{INSPECTION REPORT}

\section{INSPECTION OF AN ALLEGATION REGARDING THE VOLUNTARY SEPARATION PROGRAM AT THE SAVANNAH RIVER OPERATIONS OFFICE}

\author{
RECEIVED \\ NOV 051998 \\ OSTI
}

OCTOBER 1998

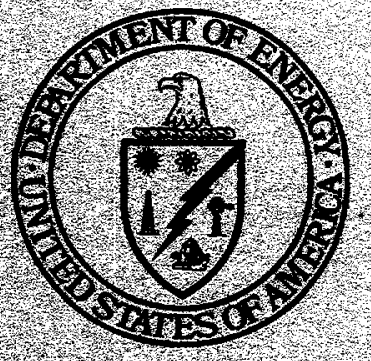

T.6. DUPARINIENT OF ENERGY OHITOF INSPECTON GENERAL VITE OF HSPECHONS

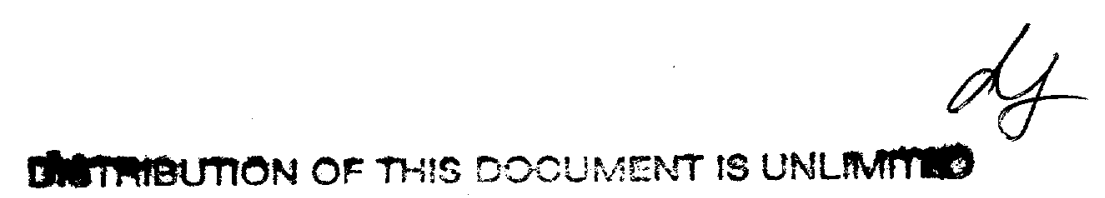




\section{DISCLAIMER}

This report was prepared as an account of work sponsored by an agency of the United States Government. Neither the United States Government nor any agency thereof, nor any of their employees, make any warranty, express or implied, or assumes any legal liability or responsibility for the accuracy, completeness, or usefulness of any information, apparatus, product, or process disclosed, or represents that its use would not infringe privately owned rights. Reference herein to any specific commercial product, process, or service by trade name, trademark, manufacturer, or otherwise does not necessarily constitute or imply its endorsement, recommendation, or favoring by the United States Government or any agency thereof. The views and opinions of authors expressed herein do not necessarily state or reflect those of the United States Government or any agency thereof. 


\section{DISCLAIMER}

Portions of this document may be illegible electronic image products. Images are produced from the best available original document. 
October 5, 1998

\author{
MEMORANDUM FOR THE SECRETARY \\ FROM: $\quad$ Gregory H. Friedman \\ Acting Inspector General
}

SUBJECT: $\quad$ INFORMATION: Report on "Inspection of an Allegation Regarding the Voluntary Separation Program at the Savannah River Operations Office"

\title{
BACKGROUND
}

In April 1996, the Savannah River Operations Office received approval from DOE Headquarters to offer Westinghouse Savannah River Company (WSRC) and Bechtel Savannah River, Inc. (BSRI) employees early termination incentives to facilitate downsizing of the contractor workforce thereby minimizing involuntary separations. In 1996, 217 individuals at the Savannah River Site (SRS) accepted a Voluntary Separation Program (VSP) incentive.

The Office of Inspector General received an allegation that a former WSRC senior manager terminated employment through a VSP program, received a large bonus for doing so, and then returned to work at the SRS without observing a required one year waiting period. We examined both the former senior manager's participation in the VSP program, and employment during the year following departure from WSRC.

\section{RESULTS OF INSPECTION}

Our inspection determined that the former senior manager terminated employment with WSRC under the VSP program. We found that the former senior manager's departure from WSRC was delayed for six months, until December 31, 1996, in order for a replacement to be relocated from Pittsburgh, Pennsylvania, to SRS and be familiarized with the position.

We also found that during 1997 the former senior manager was employed by a subcontractor supporting various Westinghouse Electric Corporation divisions, including WSRC. However, the former senior manager's labor charges for work during 1997 had not been charged to WSRC.

The underlying principle of the VSP was to allow WSRC and BSRI employees to voluntarily leave the SRS workforce, and, if necessary, only be replaced by current SRS employees. The Office of Inspector General concluded that WSRC allowed the former senior manager to participate in the VSP, and then replaced the senior manager with an 
individual from Westinghouse's headquarters in Pittsburgh. Consequently, WSRC did not meet the test of "prudent business judgment" required by its contract with DOE. We recommended that both the former senior manager's VSP bonus payment of $\$ 99,762$, as well as $\$ 36,892$ in travel and relocation costs expended to move the replacement from Pittsburgh to SRS, be recovered from WSRC.

We also recommended that the Manager, Savannah River Operations Office, determine whether any other senior WSRC or BSRI personnel who participated in the VSP were replaced by non-SRS personnel, and, if so, recover from the appropriate contractor the associated costs.

\section{MANAGEMENT REACTION}

Management concurred with the findings and recommendations.

Attachment

cc: Deputy Secretary Under Secretary 


\section{INSPECTION OF AN ALLEGATION REGARDING THE VOLUNTARY SEPARATION PROGRAM AT THE SAVANNAH RIVER OPERATIONS OFFICE}

TABLE OF CONTENTS

Overview

Introduction and Objective.............................. 1

Observations and Conclusions......................... 2

Allegation Regarding the Voluntary

Separation Program at the Savannah

River Operations Office

Details of Finding

Recommendations and Comments.

7

Appendix

Scope

9

Methodology.

9 
INTRODUCTION AND OBJECTIVE
The Office of Inspector General (OIG) received an allegation that a former senior manager of the Westinghouse Savannah River Company (WSRC) was provided an opportunity to terminate employment through a Voluntary Separation Program (VSP). The complainant wrote that after separating from WSRC, and receiving a large bonus for doing so, the former senior manager returned to work at the Savannah River Site (SRS) without observing a required waiting period of one year.

The Office of Inspector General examined both the former senior manager's participation in the VSP, and employment during the year following departure from WSRC.

In April 1996, the Department of Energy's Savannah River Operations Office (DOE-SR) received approval from DOE Headquarters to offer contractor employees at SRS both an Early Retirement Incentive and a Voluntary Separation Program. The purpose of these two programs was to facilitate necessary downsizing of the contractor workforce at the Savannah River Site by encouraging employees to leave voluntarily, thereby minimizing the number of involuntary separations. The VSP permitted people with critical skills to be offered voluntary separation incentives only if there were sufficient on-site personnel to meet mission requirements.

In 1996, 217 individuals accepted the VSP. The VSP offered participants two weeks of severance pay for each year of service, as well as medical, educational, relocation and outplacement assistance. The application period for the VSP program was from May 6, 1996, through June 20, 1996, with employment to be terminated effective June 28,1996 . Not all contractor employees would be eligible to participate in the VSP. A letter to all WSRC and Bechtel Savannah River, Inc. (BSRI) employees explaining the VSP stated that "Participation in the program may be denied by WSRC and BSRI when the loss of that competency or skill would adversely affect Site operations." In 1996, BSRI was a subcontractor who received a separate fee from WSRC. Under the current 
contract, BSRI (a subcontractor) is considered a member of the performing entity which shares the single fee paid to WSRC.

In February 1996, a document titled "Interim Planning Guidance for Contractor Work Force Restructuring," issued by DOE's Office of Worker and Community Transition, also addressed participation in the VSP. An official in SR's Contractor Human Resources told us that this guidance was provided to WSRC for use in their 1996 downsizing initiatives. Regarding "Voluntary Separation Incentives," the guidance stated that "Individuals with critical skills should not be offered voluntary separation incentives unless sufficient personnel are available to fulfill mission requirements."

OBSERVATIONS AND CONCLUSIONS
Our inspection determined that the former senior manager terminated employment with WSRC under the VSP program, in which people who participated were to have departed the site by June 28,1996 . We also found that the former senior manager's departure from WSRC was delayed for six months, until December 31, 1996, in order for a replacement to be relocated from Pittsburgh to SRS and be familiarized with the position. The OIG concluded that WSRC's actions in allowing the former senior manager to participate in the VSP, coupled with hiring an external replacement for the position, did not meet the test of "prudent business judgment" required by DOE's contract with WSRC. We recommended that both the former senior manager's VSP bonus payment of $\$ 99,762$, as well as $\$ 36,892$ in travel and relocation costs expended to move the replacement from Pittsburgh to SRS, be recovered from WSRC. We also recommended that the Manager, Savannah River Operations Office, determine whether any other senior WSRC or BSRI personnel who participated in the VSP were replaced by non-SRS personnel, and recover from the appropriate contractor the associated costs.

Following the VSP termination from WSRC, the former senior manager was employed by CDI Corporation, a subcontractor supporting various Westinghouse Electric Corporation divisions, including WSRC. We sought to determine if the former senior manager had returned to SRS, and was working without observing a required 


\section{The Former Senior Manager's Separation and Replacement}

A Higher Paid Manager Replaced the Former Senior Manager waiting period of one year. According to a WSRC financial manager, the former senior manager's labor charges for work during 1997 had not been charged to WSRC. Also, we obtained documentation that showed that the costs associated with the former senior manager's labor charges were excluded from invoices submitted to WSRC. Consequently, we are making no recommendations regarding the former senior manager's post-WSRC employment.

On June 21,1996 , the former senior manager signed an agreement to participate in the VSP. While the terms of the signed VSP acceptance stated that the former senior manager would terminate employment with WSRC effective June 28, 1996, the employment with WSRC was extended through December 31, 1996.

A WSRC Vice President told us that the former senior manager's departure was delayed beyond the scheduled June 28, 1996, VSP termination date in order for the replacement to be brought on board for continuity purposes. After leaving WSRC, the former senior manager was paid a VSP bonus of $\$ 99,762$. At the time of separation, the former senior manager's annual salary was $\$ 117,900$.

A replacement was brought to SRS from Westinghouse's headquarters in Pittsburgh, Pennsylvania, to fill the former senior manager's position. The individual commenced the new position on November 1, 1996, with a salary set at $\$ 130,524$. Based on data provided to the OIG by WSRC, travel and relocation costs associated with transferring the replacement from Pittsburgh to SRS totaled $\$ 36,892$.

At the time the former senior manager elected to take the VSP, and the offer of employment was made to the replacement, WSRC was managing the SRS for DOE under an earlier contract, DE-AC09-89SR18035. The contract clause titled "ALLOWABLE COSTS AND FEES" stated that payment for costs under this contract was based on the costs being allowable. It further stated, in part, that the determination of allowability was based on "(1) reasonableness, including the exercise of prudent business judgment." 
Replacing Former Senior Manager Negated the Purpose of the VSP Program
At the time that the former senior manager was actually paid the VSP bonus, WSRC was managing the SRS for DOE under the current contract, DE-AC09-96SR18500. The contract clause titled "ALLOWABLE COSTS AND FIXED FEE," like its predecessor contract, conditioned the allowability of costs on their being reasonable. A cost was further defined as "reasonable" if "it does not exceed that which would be incurred by a prudent person in the conduct of competitive business."

The purpose of the VSP was to facilitate a reduction in the size of the workforce at the Savannah River Site. The "FY 1995 Worker Transition and Community Assistance Plan," was carried over for use in FY 1996 and stated that "Early retirement and voluntary separation incentives were developed to maximize the number of employees able to leave the [Savannah River] Site of their own choice, thereby reducing the number of workers involuntarily separated."

While the purpose of the VSP was to assist in reducing the number of employees at SRS, the VSP was not intended, nor required, to be offered to everyone. DOE Headquarters' "Interim Planning Guidance for Contractor Work Force Restructuring," dated February 1996, stated, under the section on Voluntary Separation Incentives, that "Individuals with critical skills should not be offered voluntary separation incentives unless sufficient personnel are available to fulfill mission requirements." WSRC incorporated this guidance in a letter that explained the VSP to all WSRC and BSRI employees, which stated that "Participation in the program may be denied by WSRC and BSRI when the loss of that competency or skill would adversely affect Site operations."

We were told by a WSRC official, that DOE-SR did not approve or disapprove individuals being allowed to participate in the VSP, but only the number of slots for each targeted skill classification. The official said that after DOE-SR learned that the former senior manager would be leaving through the VSP, the DOE-SR Assistant Manager for Administration gave verbal approval for WSRC to fill the former senior manager's position, but did not give 
approval regarding the specific person chosen to fill this position. The official said that bringing the replacement from Pittsburgh to fill the former senior manager's vacated position was a Westinghouse decision; DOE-SR was not involved. Additionally, the official said that because the position was not specified by the contract as a "key position," DOE-SR's approval was not required.

We concluded that allowing the former senior manager to participate in the VSP would have been a reasonable action if the position remained vacant, or if the position was filled internally by another individual from the SRS workforce. With either of these alternatives, the purpose of the VSP, i.e., a reduction in personnel at SRS, would have been achieved. Although WSRC passed on guidance to employees advising them that they could not participate in the VSP when "the loss of that competency or skill would adversely affect Site operations," WSRC allowed the former senior manager to take the VSP. Contrary to the above contractual requirement, we believe that WSRC's actions in filling the former senior manager's position with an individual brought from another location were neither reasonable nor prudent. Given that the objective of the VSP was to reduce personnel at SRS, WSRC's actions completely negated this purpose. We concluded that a prudent business person would not pay an individual $\$ 99,762$ for the purpose of reducing SRS staff, then pay $\$ 36,892$ to relocate another individual to occupy the same position with a salary increase of $\$ 12,624$ per year.

As stated earlier, between the time the former senior manager was accepted in the VSP and later left WSRC, WSRC was operating under two different contracts with DOE. Each of these contracts stated that the payment of costs under the contract was based on the costs being allowable and reasonable. Under the earlier contract, reasonableness was explained to include "the exercise of prudent business judgment." Under the current contract, reasonableness is explained as not exceeding "that which would be incurred by a prudent person in the conduct of competitive business." In our opinion, WSRC's expenditures pertaining to the former senior manager's participation in the VSP, coupled with the expenditures related to filling the position with a Westinghouse 
employee from Pittsburgh, fail tests of reasonableness as stated in the contracts, and therefore are unallowable.

No One Was Denied An Available VSP Slot
We asked a WSRC Vice President to explain WSRC's decision to let the former senior manager participate in the VSP and then to replace the individual by relocating someone from Westinghouse's Pittsburgh office. The Vice President stated the following regarding implementation of the VSP: 1) WSRC identified the job categories and the number of slots within each job category that it wanted to eliminate by the VSP; 2 ) the only restriction WSRC placed on an individual participating in the VSP was whether a VSP slot was available in that individual's particular job category; 3 ) no individual was prohibited from participating in the VSP, regardless of their importance to the organization, if a VSP slot was available in their job category; 4) WSRC allowed all VSP applicants to participate, subject to slot availability, in order to avoid possible discrimination lawsuits; and, 5) if WSRC had reviewed the candidates, and held some back but not others, then WSRC could have possibly been sued for discrimination. Disappointed candidates could have claimed that they had been prevented from participating because of age, gender, race, etc.

The WSRC Vice President also stated that because WSRC had not restricted individuals from participating in the VSP, certain senior managers had left WSRC and had to be replaced to ensure the effective administration of DOE's contract. The Vice President said that since the former senior manager participated in the VSP, the position had to be filled for his organization to remain effective. Further, because no suitable internal candidates were identified, the replacement was hired out of Westinghouse's Pittsburgh office to fill the former senior manager's position.

As explained above, because WSRC allowed all VSP applicants to participate in the program in order to avoid possible lawsuits, WSRC then needed to replace those senior managers who left WSRC to ensure effective administration of the DOE contract. This explanation raises obvious concerns about the number of senior management positions which may have been handled in this manner. Paramount among these concerns is the cost involved with paying these senior managers to leave 
and subsequently paying the cost to fill the vacated positions from outside of the existing SRS workforce.

In light of the WSRC Vice President's statement during this inspection that certain other senior managers were also replaced, we concluded there is a possibility other senior positions vacated through the VSP were filled from outside of the SRS workforce as well.

Consequently, DOE-SR should determine if any other WSRC or BSRI senior manager positions were vacated through the VSP and then filled from outside of the SRS workforce, and if so, recover the associated costs.

RECOMMENDATIONS

\section{MANAGEMENT COMMENTS}

We recommend that the Manager, Savannah River Operations Office:

1. Recover from WSRC the cost of the former senior manager's VSP bonus of $\$ 99,762$, and all travel and relocation costs associated with moving the replacement from Pittsburgh to SRS, currently indicated to be $\$ 36,892$.

2. Determine whether any other senior WSRC or BSRI personnel who participated in the VSP were replaced by non-SRS personnel and then recover from the appropriate contractor the related VSP bonus costs as well as any travel and relocation expenses involved.

Management concurred with the findings and recommendations and agreed to take corrective action. The Manager, Savannah River Operations Office, agreed that the offer of a VSP package to a senior manager and promptly hiring an outside replacement, conflicted with the February 1996 Workforce Restructuring Interim Guidance. The Manager stated that DOE-SR will pursue recovery of unallowable and/or unreasonable costs incurred by WSRC in vacating and filling the former senior manager's position. The Manager further stated that they will work with WSRC to clarify issues regarding action taken and discuss actions with legal counsel to determine the appropriate amount of funds that should be recovered. 
The Manager also stated that DOE-SR will review WSRC and BSRI employment records to determine if any other senior personnel participated in the VSP, and were replaced by non-SRS personnel, and pursue recoveries as appropriate.

INSPECTOR COMMENT We consider management's comments to the recommendations to be responsive. 
Appendix

SCOPE

METHODOLOGY
The inspection was performed at the Savannah River Operations Office in Aiken, South Carolina, from July 1997 through June 1998.

This inspection was conducted in accordance with the "Quality Standards for Inspections" issued by the President's Council on Integrity and Efficiency. As part of our inspection we interviewed officials at DOE's Savannah River Operations Office and Westinghouse Savannah River Company. We also reviewed pertinent records and documents pertaining to the Voluntary Separation Program.

Page 9

Scope and Methodology 
IG Report No. INS-0-99-01

\section{CUSTOMER RESPONSE FORM}

The Office of Inspector General has a continuing interest in improving the usefulness of its products. We wish to make our reports as responsive as possible to our customers' requirements, and therefore ask that you consider sharing your thoughts with us. On the back of this form, you may suggest improvements to enhance the effectiveness of future reports. Please include answers to the following questions if they are applicable to you:

1. What additional background information about the selection, scheduling, scope, or procedures of the audit or inspection would have been helpful to the reader in understanding this report?

2. What additional information related to findings and recommendations could have been included in this report to assist management in implementing corrective actions?

3. What format, stylistic, or organizational changes might have made this report's overall message more clear to the reader?

4. What additional actions could the Office of Inspector General have taken on the issues discussed in this report which would have been helpful?

Please include your name and telephone number so that we may contact you should we have any questions about your comments.

Name Date

Telephone Organization

When you have completed this form, you may telefax it to the Office of Inspector General at (202) 586-0948, or you may mail it to:

Office of Inspector General (IG-1)

U.S. Department of Energy

Washington, D.C. 20585

ATTN: Customer Relations

If you wish to discuss this report or your comments with a staff member of the Office of Inspector General, please contact Wilma Slaughter at (202) 586-1924. 
The Office of Inspector General wants to make the distribution of its reports as customer friendly and cost effective as possible. Therefore, this report will be available electronically through the Internet at the following alternative address:

Department of Energy Human Resources and Administration Home Page http://www.hr.doe.gov/ig

Your comments would be appreciated and can be provided on the Customer Response Form attached to the report.

This report can be obtained from the

U.S. Department of Energy

Office of Scientific and Technical Information

P.O. Box 62

Oak Ridge, Tennessee 37831 